\title{
Mothers' Knowledge of Nutrition and Feeding Practices: A Case Study on Kampung Sehat STIKES Mataram, West Nusa Tenggara Province, Indonesia
}

\author{
Chairun Nasirin \\ College of Health Science (STIKES Mataram), Lombok, Indonesia
}

\begin{abstract}
Health issues marked with a variety of diseases spreading amid the community, lack of sanitary facility, and unhealthy daily practice of the community havenegatively influenced Indonesia's human development index. In line with the government program to eradicate poverty and drawbacks in the community and within the larger initiative of Kampung Sehat STIKES Mataram, this research explores mothers' knowledge about nutrition and feeding practices in Mataram, Indonesia. For this purpose, the researcher used a case study that deals with a single community as a case to see its particularity and complexity.Mothers under investigation generally have poor knowledge about nutrition and feeding their infant as a result of their adherence tocultural beliefs and feeding practices. Therefore, educational interventions need to be made to change their cultural beliefs and practice in order to improve their knowledge of nutrition and feeding practices for better health of the community.
\end{abstract}

Keywords: Mother's Knowledge, Health, Feeding Practices, Community Empowerment, Nutrition.

\section{INTRODUCTION}

Health has become one of crucial issues in Indonesia's human development index. The preamble of Indonesia's Law Number 36 of 2009 on Health (Undang-Undang Republik Indonesia Nomor 36 Tahun 2009 Tentang Kesehatan) reads "bahwa kesehatan merupakan hak asasi manusia dan salah satu unsur kesejahteraan yang harus diwujudkan sesuai dengan cita-cita bangsa Indonesia sebagaimana dimaksud dalam Pancasila dan Undang-Undang Dasar Negara Republik Indonesia Tahun 1945" (that health is a human right and an element of welfare that has to be realized in accordance with the nation's mission statement as intended in the nation's five pillars[Pancasila] and the state's constitution. The preamble also states that every act to preserve and improve public health to the highest degree shall be carried out based on the principles of non-discriminative, participative, and continuous for the sake of shaping Indonesian human resources and increasing national resilience and competitiveness for national development. Further, article 3 of the act reads that health development aims to raise people's awareness, willingness, and ability towards healthy life for every individual in order to materialize the highest level of public health as an investment for the development of human resources characterized with social and economic productivity.

Health issues are marked by a variety of diseases spreading amid the community, lack of sanitary facility, and unhealthy daily practice of the community members (Keman, 2005). Sanitary-related diseases such as diarrhea and malaria as often found in tropical areas easily spread out. Then in relation to the lack of sanitary facility, it is usual to see houses made of bamboo without toilet inside, rooms without ventilations for air circulation or light spots, ground floor without ceramic, and yards without garbage bin. Likewise, unhealthy life style such as spitting, eating junk food, and smoking has become a normal depiction of the village under scrutiny. Efforts have been made by the government to eradicate the poverty, as a potential barriers in the improvement of these areas, while improving health through prevention and treatment to increase social welfare of the local people (Nasirin, 2010; 2013).

In line with the local government program to eradicate poverty and drawbacks in the community and in response to the local people's needs for health empowerment, Mataram Health College (STIKES Mataram)has introduced a model of health empowerment called "Kampung Sehat STIKES Mataram" 
in 2016. As a new strategy of community empowerment, this program involves a variety of activities and local wisdom. The activities include the provision of supplemental nutrients for malnourished children, special care for pregnant women and geriatric members of the community, and free medical check-up, medication, and other treatments for the local community. In addition, Kampung Sehat also provides health education for the local community. The education includes clinical training for the people to use first aid treatment and deal with a trauma.

Within the larger initiative of Kampung Sehat STIKES Mataram, this research exploresmothers' knowledge about nutrients in relation to child's health. The researcher looked for health and nutrition behavior in those taking care of the children and tried to change them. For this purpose, the researcher used a case study that deals with a single community as a case to see its particularly and complexity through an in-depth understanding of socialcultural context in which participants in a particular community (case) engage in a certain set of behaviors and make sense of their interaction (HesseBiber\&Leavy, 2011).Focus was given to the mothers' knowledge on nutrition and feeding practices as parts health management of the family and community on the research site.

\section{Previous Research}

It was widely reported that undernutrition has greatly affected the life children all over the world. Approximately, over 8 million children under 5 years of age died all over the world in 2010, with undernutrition contributing to $35 \%$ of these deaths (Black et al. 2008; UNICEF 2010). In Indonesia the value for infant mortality rate (per 1,000 live births) was 22.80 as of 2015 . Over the past 55 years this indicator reached a maximum value of 148.40 and a minimum value of 22.80 in 2015 (United Nation, 2015). The West Nusa Tenggara Province, where the study is located, has been known as one of the province in Indonesia with the highest recorded infant and child mortality and it has become one of the most well-known "fact" of contemporary Indonesia concern with child survival (Hull, Rusman\& Johan, 2014). For the surviving children, their undernutrition during the critical 1000 dayperiod between conception and 24 months may have lifelong effect. For example, children who are undernourished in early childhood are more likely to suffer from cognitive deficits (Mendez \& Adair 1999; Berkman et al. 2002; Liu et al. 2003). When they grow older, they also have an increased risk of chronic disease (Sawayaet al. 2003; Uauyet al. 2008), as well as a greater possibility of permanent short physique, lower academic achievement and lower economic status (Victoraet al. 2008, 2010).

Kruger and Gericke (2003) reported from different sources that chronic malnutrition is a common phenomenon indeveloping countries. For example, the researchers found that black preschoolchildren in South Africawere suffering one of chronic malnutrition, caused by a dietlow in energy over a long period of time. This problem had to do with breast-feeding and weaning practices and theeating habits of children shortly after weaning between age 6 and 36months. Poor infant feeding and weaning practices(food shortages and imbalances) resulted in children's stuntedgrowth, delayed motor and mental development, immuneincompetence, frequent attacks of diarrheal disease,macro- and micronutrient deficiencies and, most importantly,interference with the realization of full humanpotential (Kruger\&Gericke, 2003).

Malnutrition has also been a public health problem in Indonesia. Adequate nutrition is often not met by the child, in particular due to a variety of factors, including the socioeconomic status of the family and educational level of the family. Mazarina Devi (2010) identifies factors related to the malnutrition of children in rural areas. Based on the cross-sectional survey design, using the age of the child, the parent child sex, age, level of the parent education, parent occupation, family size, and duration of breast feeding as independent variables, while using the nutrition status based on the anthropometric as a dependent variable. The results of logistic regression test revealed that the most dominant factor associated with nutritional status is the father and mother occupations (Devi, 2010).

Linda Maas (2004) in her article entitled Kesehatan Ibu dan Anak: Persepsi Budaya dan Dampak Kesehatannya (Mother and Child's Health: Cultural Perception and Its Impact on Health) contended that Indonesia's government has implemented a variety of health programs intended to eradicate health issues on mothers and children. These programs are basically focused on reducing the rate of infant and child mortality, the natality rate, and the mortality rate of mothers. Other than mortality rate, morbidity rate has become a part of mother and child's health issue. The morbidity deals with a variety of diseases, such as upper respiratory infection, diarrhea, and tetanus, which are usually 
suffered by infants and children and often lead to the death. It also deals with varying diseases frequently suffered by pregnant women, including anemia, hypertension, hepatitis etc. all that lead to a serious risk for the women prior to, during, and after giving birth.

Still according to Maas (2004), both mortality and morbidity issues are influenced by social, cultural, and physical environments of the community. These factors include their belief, cultural knowledge, such as the concepts of taboo, causal relationship of food and health or illness, food and meal patterns, eating habit, and ignorance of food and health-related practices. Maas (2004) further argues that each community has its own rules describing the quantity, quality, and types of food they should or should not have. Likewise, families have their own convention about the food the family members can consume with regard to their social status, age, sex, and/or situations. No matter what rules or habit enforced by the community or family, the main figure that plays a very significant role in arranging daily menu and distributing food to family members is the mother as the food keeper of the family.

UNICEF(1998) categorizes the causal factors of malnutrition into direct cause, indirectcause, key problem, and the root of the problem. The direct causes include imbalanced menu and infection, whereas indirect causes consist of food resilience in the family, pattern of child rearing, and health services and sanitation. The root of the problem is concerned with poverty and sociopolitical chaos, in which many of the population live below poverty line. The inability of the people to provide energy, protein, micronutrients affects child's growth and development, immune functions, and reproductive system for women. Research by Mossman, Heaman, Dennis, and Morris (2008) on breastfeeding mothers in the province of Manitoba, Canada suggested that the social and economic disadvantages experienced by many adolescent mothers place their infant at significantly greater risk for infant mortality, morbidity, and developmental delays.Micronutrient deficiency is frequently found during the period of speed growth, pregnancy and breast feeding. Low intake of micronutrient during pregnancy increases risk for women and harmful birth outcome.

Other factors that influence nutrient status for a child include economic status of the family, which affects eating pattern and nutrient adequacy for the child; socio-cultural factor that places the need of pregnant women after the need of husbands as family head and their children; and educational factor, which is usually low, that negatively affects women knowledge of healthy lifestyle and of the importance of nutrients for child's health and nutrient status. AndrianiPahlevi (2012) argues that the under nourishment is directly caused by unbalanced nutrients in the food consumed and the spread of inflectional diseases. Whereas, the indirect cause includes food resilience of the family, pattern of child rearing, and health service provided. These three factors are closely related to the family's level of education, knowledge, skill, and income. More than that, the mother plays a key role in preparing and providing nutritious food for the family that leads to children's nutrient status (Lazzeriet al., 2006; Rina, 2008).

Exposure to education and information could enable mothers to make the best use of theresources available to them to overcome some of the difficulties (Joshi, 2011; Lazzeri et al., 2006; Salehi et al, 2004), but whether nutrition education alone can successfully improve the diets of children suffering from extreme poverty still remains unclear. Nonetheless, research on nutrition education program conducted by Salehi (2004) in forty subtribes located in Fars Province, Iran revealed that nutrition education programs might be more effective if they were supported by a sound theory specifically addressing change in nutrition behavior. A model for behavior change that has the potential to be employed for nutrition education programs is Hubley's (1993) behavioral change model, the components of which deal with beliefs, attitudes, subjective norms and enabling factors (BASNEF). The subjective norms according to this model are beliefs about the types of behavior certain influential individuals want the targeted subject to display. Along with, enabling factors, such as income, housing, water supply and food production, must also be available in order for the change in behavior to take place.

According to the BASNEF model, individual beliefs about the consequences of certain behaviors and the value placed upon each consequence lead to personal attitudes or judgements. These attitudes, combined with the subjective norms of the community and intersectoral enabling factors, contribute to behavioral intention (Hubley, 1993; Salehi, 2004). So, the individual person's behavior becomes the starting point for this model to apply. However, an understanding of the influences on behavior may lead to intervention that extends beyond the individuals. Therefore, this model may be used to address 
programs at the family, community and national levels: it can also involve social, economic, educational, and political changes. Above all, it can be used to explain how individuals intentionally change their behavior, when such behavioral changes happen, what tools they use specifically and what indicators they use to measure the change effectiveness.

\section{MeTHODS}

Methodology refers to the whole procedures by which researchers perform their work that includes describing, explaining and predicting phenomena under scrutiny. Aiming to provide the work plan of research, methodology informs the strategies the researchers used to obtain knowledge of the phenomena being investigated. The methodological aspects of this research include the discussion of the research setting, participants, researcher-participants relationship, design and instruments, data analysis, and the research timeline.

Setting of this research is asuburban neighborhood named Lingkungan Mapak Dasan, Jempong Baru, Mataram, West Nusa Tenggara Province. This neighborhood is located just outside of Mataram city ring road. This neighborhood was chosen as a research site because of some reasons, including the lack of health facility around the site and the proximity of the site to the campus of STIKES Mataram.

Participants of this study consisted of 29 female aged between 18 and 36with formal education ranging from elementary school $(n=8)$, junior high school $(n=10)$ to senior high school $(n=11)$. These parents are relatively younger with age averaging 26.83 years old and lower education, that is, mostly below senior high school level.The sample selection was based on their response to the questionnaires and willingness to further participate in the research study. Then, the participants were asked to fill out a questionnaire and interviewed about their knowledge about child feeding.

\subsection{Design}

This qualitative research study was designed to use a case study of a community from the perspective of health practice and education. Case study deals with a single case or entity to see its particularity and complexity. Cases are primarily people, but a case can be a program, an institution, an organization, or a community (Dörnyei, 2007). Dörnyei asserts that almost anything can be considered a case as long as it constitutes a single entity with clearly defined borders. A case study consists of a detailed investigation of phenomena within their context over a period of time (Hartley, 2004). It can also cover an extended period of time examining the case in its natural surroundings, making it partially or wholly longitudinal in nature (Creswell, 2007;Dörnyei, 2007). This involves a researcher to become immersed in the everyday shared activities of the community the researcher will observe and interview. I chose case study methods to collect data as this research aimed to obtain an in-depth understanding of sociocultural contexts in which participants in a particular community (case) engage in a certain set of behaviors and make sense of their socialization processes (HesseBiber\&Leavy, 2011) in order to reproduce the cultural behavior in relation to health practice and education.

\subsection{Instruments}

Qualitative researchers normally make use of four primary methods for collecting data, including participation in the setting, direct observation, in-depth interview, and document and material culture analysis (Marshall \&Rossman, 2011). Likewise, data for case study research can be obtained through observations, interviews, and document archives (Dörnyei, 2007). Actual case studies even incorporate quantitative data collection instruments such as questionnaires (Verschuren, 2003). Following these scholars, this research study made use of both participant and non-participant observations, focus-group interviews, documentary and artifact analysis, and questionnaires.

\section{RESUlts AND Discussion}

Piles of data from different sources-field notes from observations, interview transcripts, filled out questionnaires, documents, and artifacts were soon analyzed, starting from coding, categorizing, and writing analytic memos. By means of coding the data were grouped into conceptual categories either deductively or inductively, or some combination of the two (Saldaña, 2009). Saldaña suggests to "[s]tart coding as you collect and format your data, not after all fieldwork has been completed" (p. 17, emphasis in original). Following coding process, analytic memos were written down to document and reflect on coding process and code choices, and even added new codes and categories. Knowing that 
qualitative research analysis is not a separate stage, researchers could always go back and forth between different processes or stages of data analysis until they finished writing up the research (Wolcott, 2009). Coding and memoing for this research were conducted manually, considering the scarcity of computer-assisted data analysis tool on research site.

Data of this research study are presented as follow:

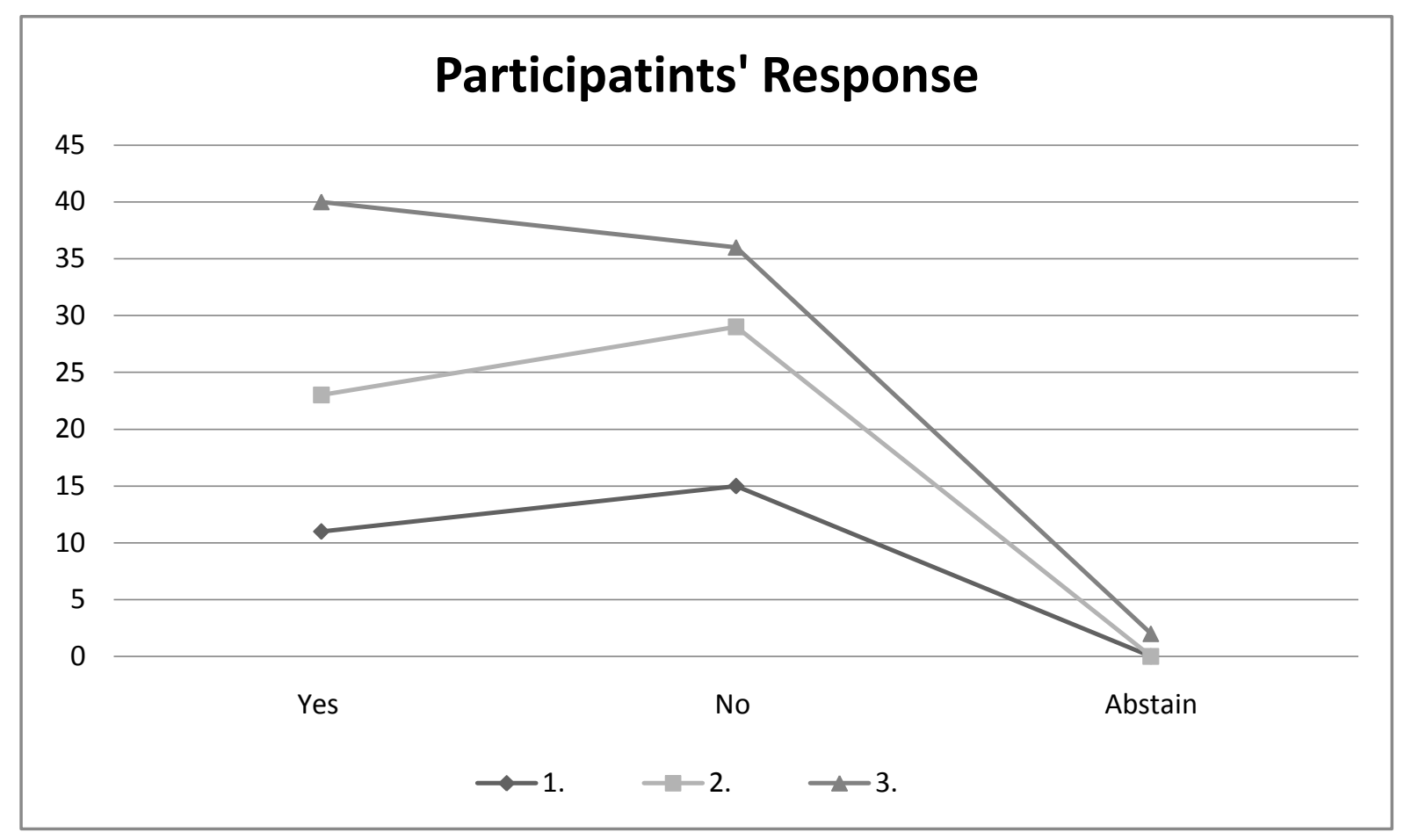

Figure 1. Participants' Response toQuestionnaire

The aforementioned data reveal that the parents under observation are split almostequally in terms of their knowledge about the age in which a baby can be fed on with food other than breast milk. The data also reveal that more than a quarter of the parents admitted of not knowing the reason why a baby cries after being fed on. All this information provides insights into how minimal the parents' knowledge about what to provide for a baby, when, and how it affects the baby's behavior.

This minimal knowledge is reflected on the parents' responses to the question "Do you know the impacts of feeding on the baby (with additional food) before the proper time? If so, what are they?" A mother just responded with a short phrase "Tidak tahu" (No idea, meaning I have no idea.). However, other parents provided varying answers from as short as one word to a more elaborated sentence. For example, a few parents said, "Sembelit" (Constipation) to refer to a situation when it is difficult for a child to poo. A mother said, "Pencernaanterganggu" (Its digestive system would be disordered.) A more elaborated response was provided by another mother,who explained, "Its digestive system would be obstructed because its colon is not yet strong enough if it is given food other than breast milk, and if so given, the baby would frequently fall sick."

Similar responses include an explanation by another mother, who explained, "A baby would easily have a stomachache because its colon is still too small." Another mother argued that food other than mother's breast milk is not good for baby's colon. Other response reads, "It obstructs baby's digestive system and appetite." "Colon is still young and week to digest food." "The baby would experience digestive disorder." "When it grows bigger, the baby would fall sick more frequently." However, there were answers that related the provision of food before its appropriate time with not only digestive but also respiratory system. A respondent said, "It bothers colon and inhalation," while another parent said, "It usually bothers breathing tract." There was even an answer that related it with the nutrient deficiency syndrome as reflected in the response by a participant, who said, "The baby would suffer malnutrition." 
When asked about what they know of the benefit of side food for a baby and asked to mention them, the parents provided the following responses: A parent said that the baby would grow healthy and active. Another mother responded, "[It] would add nutrient intake for the baby." Another mother combined the two previous answers into, "To help the baby grow and add nutrient intake for the baby." Similar answers are listed as follow: "To fulfill the need for additional food." "To accelerate the growth of the baby." "It helps the child's growth." "To improve [child's] growth" "Body immune." "For the baby to grow healthy and active."

For the question of whether or not they know about the balanced menu for children under five years, part of the parents said no, while others responding with yes. The latter provided the answer with the kind of food they thought should be given more for a baby and a child under five year. The types of food they mentioned include milk, tofu, tempeh, meat, rice, fish, biscuits, lever, and eggs with porridge, fruits, and vegetables being the most chosen by the participants. One parent explained that the balanced menu for children under five years should include the food that contains vitamins, such as porridge, milk, fruits, and vegetables. In line with this, in answer to the question of what is the best food other than breast milk that should be given the first time to a baby, most of the parents answered with either fruits or porridge. However, one mother said immunization, while many of the participants did not answer.

In response to the question of whether they know the characteristics of a healthy child, the parents provided the following criteria, including being active when playing; being physically fit, eating a lot; playing actively and rarely getting sick; drinking a lot of milk; being vibrant and responsive; having constant increases in body weight, being active, responsive, cherish, vibrant, joyful, agile, and skillful. The other criteria include that the older the children grow, the healthier and stronger they get; the more weight they gain, and the taller and healthier they get, indicated for example by that their height and weight increase every month. Healthy children also sleep soundly, eat with high appetite, and can repeat or do what it sees. Above all, healthy children have the combination of all and/or some of the aforementioned features.

In regard to the question of the types of food good for a baby of seven month old, almost all the parents answered with porridge. Others said rice, especially softer rice mixed with lever, egg, vegetables, and sometimes juicy drinks. A parent suggested the child be given softer porridge made of rice so it is more easily digested. Other parent suggested porridge, biscuits, and fruits; bread; milk; biscuit; rice; softer porridge; porridge and fruits.

The fact that mothers relatively have poor knowledge of feeding on their babyis similar to the research findings throughout the world. Research by Kruger and Gericke (2003), for example, suggests the participant's nutrition knowledge regarding specificfoods, their functions and recommended quantities was poor. Young mothers often find it impossible to ignore their ill-informed elders or peergroupregarding food choices and preparation practices,leading to poor-quality feeding practices(Kruger\&Gericke, 2003). This fact provides example of how women adhering totheir cultural practices and beliefs as well as inadequate nutrition knowledge has a powerful influence on feeding practices and eating patterns.

Therefore, mothers' knowledge of nutrition and feeding practices need to be improved. Group discussions as well as counseling that focus on possiblesolutions for the identified nutrition-related problemsneed to be facilitated. Research has suggested that counselling and education on complementary feedingcombined with food supplements can help improve child growth (Bhuttaet al., 2008). A review of data from Demographicand Health Survey revealed that mothers'education, family income, and exposure to media were allpositively tied to optimal practices (Joshiet al., 2012). Educationalinterventions that involve parents or other family members responsible for or playing a significant role in the care behavior and care resources areimportant in feeding the children nutritious but simple and cheap foods. Suchpractices could improve childgrowth even in food-insecure settings in many of developing countries (Salehiet al., 2004).

In the context of local community on the research site, the early step to help the mothers and their baby requires the ability toidentify mothers at risk as early as possible. Once we identified the mothers who would like to breastfeed their baby, we follow it up with mothers' schooling to improve their mind set, intention, self-efficacy, and earlier Breast feeding experience. An intervention should aim at 
changing their mindset and practices, improving the self-efficacy and resources of thesemothers, with a focus on practical knowledge.

\section{Conclusions}

To sum up, mothers under investigation generally have poor knowledge about feeding on their infant, such as how long they have to exclusively breastfeed, what type of food is good for their infant during breastfeeding, and why the babies cry after being milk- or breastfed. Except for a few, parents have little knowledge of the impacts of providing a baby with additional food during the period of breastfeeding. Despite their varying level of knowledge of the benefit of supplement food for a baby, the mothers know little about the balanced menu for children under five years evidenced in that a number of parents frankly expressed their ignorance about it. Similarly, almost all the parents answered with porridge in response to the question of the types of food good for a baby of seven month old. However, many of the participants could describe the characteristics of a healthy child, such as being physically fit, eating a lot, actively playing, and rarely getting sick.

This current research shows that the mothers under investigation apparently have poor knowledge about nutrition and feeding their baby. This has to do with their level of knowledge and adherence to their cultural beliefs and feeding practices inherited from their ancestors. Thisresult provides insights into the importance of education interventions through counseling and discussions need to be made in order to improve their knowledge of nutrition and feeding practices. The interventions may begin with anearly identification of mothers at risk is important as part of the program to support mother and child's health. The following steps of the program can focus on changing their misconceived feeding practices, improving their practical knowledge of nutrition andits resources. This understanding of parents' knowledge about infant feeding may be used as a basis for local authority and other stakeholders to provide adequate program that can improve mothers' knowledge along with health care to the community under investigation.

Research-wise, this study provides a preliminary step to the study specifically addressing change in nutrition behavior. Future research may apply Hubley's (1993) behavioral change model in relation to nutrition education programs. The components of this model include beliefs, attitudes, subjective norms and enabling factors (BASNEF). According to the BASNEF model, individual beliefs about the consequences of certain behaviors and the value placed upon each consequence lead to personal attitudes or judgments. These attitudes, combined with the subjective norms of the community to enabling factors, contribute to behavioral intention (Hubley, 1993; Salehi, 2004). So, the individual person's behavior becomes the starting point for this model to apply. However, an understanding of the influences on behavior may lead to intervention that extends beyond the individuals. Therefore, in the long run, the future research may be applied to address programs at the family, community and national levels: it can also involve social, economic, educational, and political changes.

\section{REFERENCES}

[1] Bhutta, Z. A., Ahmed, T., Black, R. E., Cousens, S., Dewey, K., Giugliani, E. (2008). What works? Interventions for maternal and child undernutrition and survival. The Lancet, 371, 417440.

[2] Creswell, J. W. (2007). Qualitative inquiry and research design. Choosing among Five Approaches $\left(2^{\text {nd }}\right.$ ed.). Thousand Oaks, CA: Sage Publications, Inc.

[3] Depkes RI. (2005). Pedoman Perbaikan Gizi Anak Sekolah Dasar, dan Madrasah Ibtidaiyah (Guidelines for Improving Nutrients of Elementary School Children). Jakarta: Direktorat Gizi Masyarakat.

[4] Devi, M. (2010). Analisis faktor-faktor yang berpengaruh terhadap status gizi balita di pedesaan (Analysis of factors influencing nutrient status of children under five years in rural villages). Teknologidan Kejuruan, 33(2), 183-192.

[5] Dewey, K. G. \&Adu-Afarwuah, S. (2008). Systematic review of the efficacy and effectiveness of complementary feeding interventions in developing countries. Maternal \& Child Nutrition, 4, 24-85.

[6] Dörnyei, Z, (2007). Research methods in applied linguistics. Oxford: Oxford University Press. 
[7] Hartley, J. (2004). Case study research. Essential guide to qualitative methods in organizational research, 323-333.

[8] Heath, D. L. \&Panaretto, S. K. (2005). Nutrition status of primary school children in Townsville. Aust. J. Rural Health, 13, 282-289.

[9] Hesse-Biber, S. N. \&Leavy, P. (2011). The practice of qualitative research $\left(2^{\text {nd }}\right.$ ed.). Thousand Oaks, CA: SAGE.

[10] Hubley, J. (1993). Communicating health: an action guide to health education and health promotion. London: Macmillan Press.

[11] Joshi, H. S. (2011). Determinants of nutritional status of school children. A cross sectional study in the western region of Nepal. NJIRM, 2(1), 10-15.

[12] Hull, T.H. Rusman, R., \&Djohan, E. (2014). RethinkingEstimates of Infant Mortality in Nusa Tenggara Barat. Available online at http://www.reserchgate.net/publication.

[13] Joshi, N., Agho, K. E., Dibley, M. J., Senarath, U., \& Tiwari, K. (2012). Determinants of inappropriate complementary feeding practices in young children in Nepal: Secondary data analysis of Demographic and Health Survey 2006. Maternal \& Child Nutrition, 8, 45-59.

[14] Keman, S. (2005).Kesehatanperumahan(Housing health).JurnalKesehatan Lingkungan, 2(1), 2942.

[15] Kronborg, H. \&Væth, M. (2004). The influence of psychosocial factors on the duration of breastfeeding. Scand J Public Health, 32, 210-216. doi: 10.1080/14034940310019218

[16] Kruger, R. \&Gericke, G. J. (2003). A qualitative exploration of rural feeding and weaning practices, knowledge and attitudes on nutrition. Public Health Nutrition, 6(2), 217-223 doi: 10.1079/PHN2002419

[17] Lazzeri, G., Casorelli, A., Giallombardo, D., Grasso, A., Guidoni, C., Menoni, E., Giacchi, M. (2006). Nutritional surveillance in Tuscany: Maternal perception of nutritional status of 8-9 y-old school-children. Journal of Preventive Medicine and Hygiene, 47, 16-21.

[18] Maas, L. T. (2004). Kesehatan ibu dan anak: Persepsi budaya dan dampak kesehatannya (Mother and child health: Cultural perception and its impact on health). USU Digital Library. Retrieved on August 17, 2016 from www.USU Digital Library.

[19] Marshall, C. \&Rossman, G. B. (2011). Designing qualitative research (5 ${ }^{\text {th }}$ ed.). Thousand Oaks, CA: SAGE.

[20] Mossman, M., Heaman, M., Dennis, C. L., \& Morris, M. (2008). The influence of adolescent mothers' breastfeeding confidence and attitudes on breastfeeding initiation and duration. Journal of Human Lactation, 24(268). doi: 10.1177/0890334408316075.

[21] Mukherjee, M. R., Chaturvedi, L. S. C., Bhalwar, C. R. (2008). Determinants of nutritional status of school children. MJAFI, 64(3), 227-231.

[22] Nasirin, Chairun. (2010). Kebijakan pemerintah daerah dalam penyelenggaraan urusan pemerintahan bidang kesejahteraan social (The implementation of local government policy in the area of social welfare). Jurnal Aplikasi Manajemen, 8(3), 680-693.

[23] Nasirin, Chairun. (2013). Program pemberdayaan Anak-anak Terlantar Di Nusa Tenggara Barat (Empowerment program for neglected children in West Nusa Tenggara). Sosio Humaniora, 15(3), 239-252.

[24] Pahlevi, A. E. (2012). Determinan status gizi pada siswa sekolah dasar (The determinats of nutrient status of elementary school children).Kesehatan Masyarakat, 7(2), 122-126.

[25] Saldaña, J. (2009). The coding manual for qualitative research methods. Thousand Oaks, CA: SAGE.

[26] Salehi, M., Kimiagar, S. M., Shahbazi, M., Mehrabi, Y., \&Kolahi, A. A. (2004). Assessing the impact of nutrition education on growth indices of Iranian nomadic children: an application of a modified beliefs, attitudes, subjective-norms and enabling-factors model. British Journal of Nutrition, 91, 779-787. doi: 10.1079/BJN20041099.

[27] Seidman, I. (2006). Interviewing as qualitative research: A guide for researchers in education and the social Sciences $\left(3^{\text {rd }}\right.$ ed.). New York: Teachers College Press. 
Mothers' Knowledge of Nutrition and Feeding Practices: A Case Study on Kampung Sehat STIKES Mataram, West Nusa Tenggara Province, Indonesia

[28] United Nations. (2015). UN Inter-agency Group for Child Mortality Estimation (UNICEF, WHO, World Bank, UN DESA Population Division). Retrieved on October 19, 2016 from www.childmortality.org.

[29] Verschuren, P. J. M. (2003). Case study as a research strategy: Some ambiguities and opportunities. International Journal of Social Research Methodology, 6(2), 121-139. doi: $10.1080 / 13645570110106154$

[30] Wolcott, H. (2009). Writing up qualitative research ( $3^{\text {rd }}$ Ed.). Thousand Oaks, CA: SAGE. 